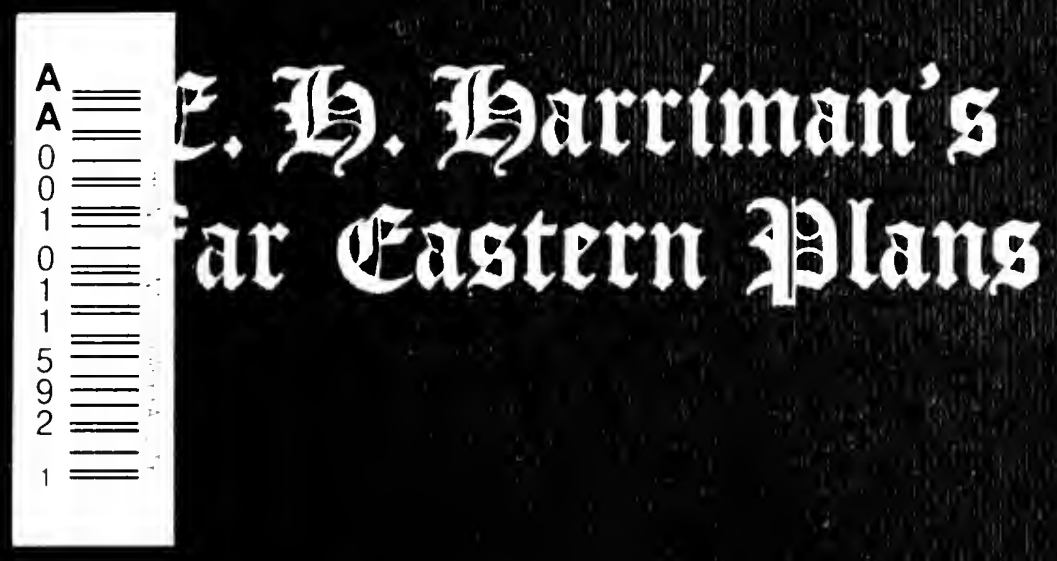

lifornia ional lity 

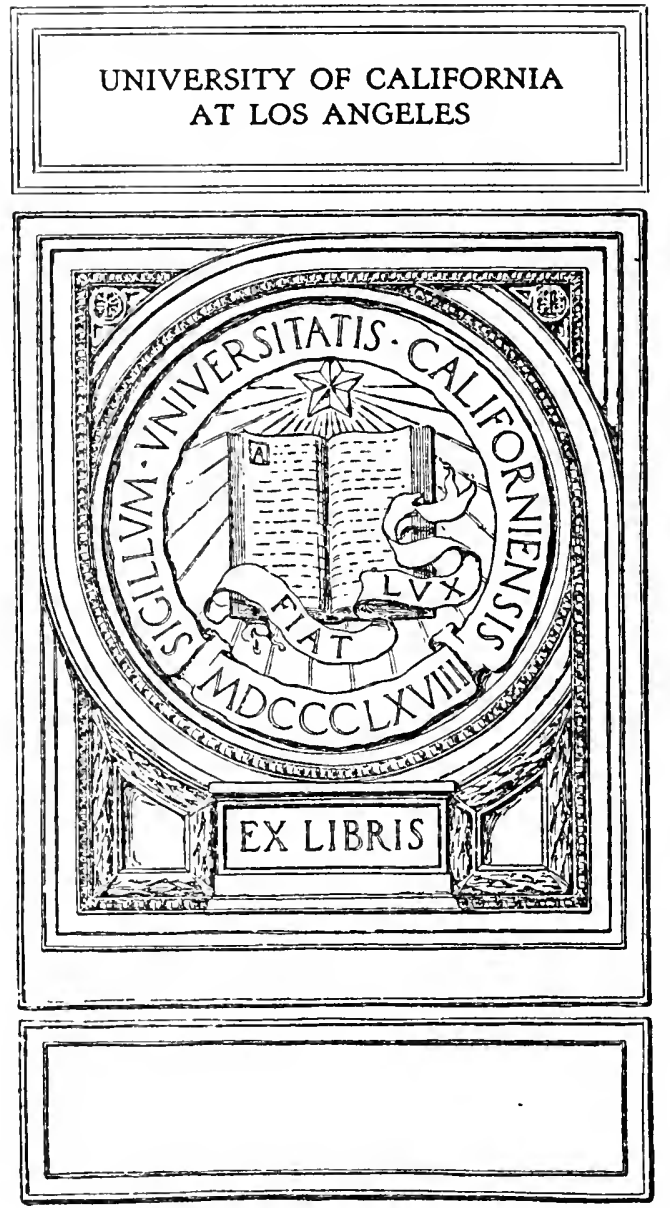
Inscumber with the complaments if lis Goorge kennur. 1338 Fifth trenue.

$$
\text { R.D.W. }
$$



- 


\section{E. H. HARRIMAN'S \\ FAR EASTERN PLANS}





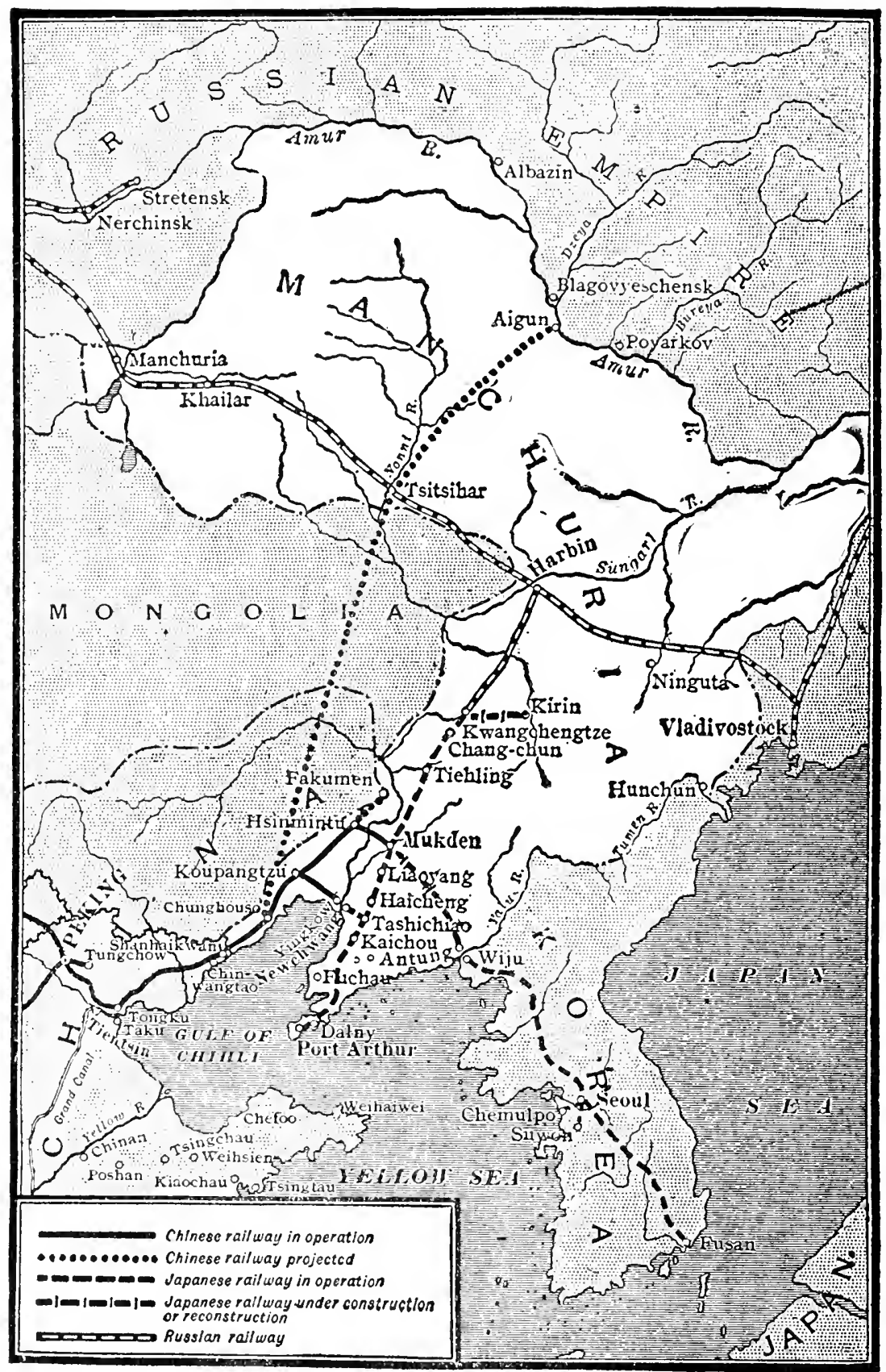




\section{E. H.Harriman's}

Far Eastern Plans

\section{By GEORGE KENNAN}

THE COUNTRY LIFE PRESS 
Copyright, 1917, by George Kennan

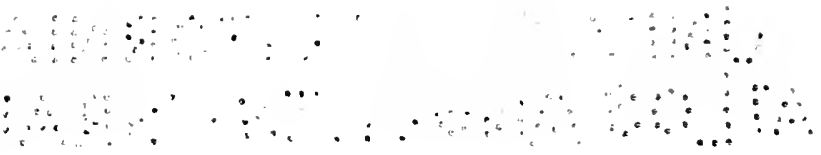




\section{E. H. HARRIMAN'S \\ FAR EASTERN PLANS}

3
3
3
$j$
$j$
$j$ 



\section{E. H. Harriman's Far Eastern Plans}

Mr. Harriman's direct business relations with the Far East began in the year 1905. The aid given by Kuhn, Loeb \& Co. to the Japanese Government in floating its war bonds, as well as Mr. Harriman's own interest in China and Japan, based on his connection with the Pacific Mail Steamship Company, early attracted his attention to that part of the world, and when in the spring of 1905 , he received an urgent invitation to visit Japan, from the American minister in Tokyo, Mr. Lloyd C. Griscom, he determined to suspend for a time his financial and railroad activities in the United States and look over per- 


\section{E. H. HARRIMAN'S}

sonally the Oriental field, with a view to ascertaining what could be done for the extension of American commerce in Far Eastern countries.

'It is important,' he said in a letter to Mr. Griscom, "to save the commercial interests of the United States from being entirely wiped from the Pacific Ocean in the future," and "the way to find out what is best to be done is to start something." This proposal to "start something" was characteristic of Mr. Harriman's methods. He did not think it necessary to perfect all the details of a plan before going to work. When he had clearly defined the object to be attained, his policy was to "start something," and then work out the scheme in accordance with circumstances and conditions as they might arise. The clearly defined object that he had in view in this case was the extension of American influence and the promotion of 


\section{FAR EASTERN PLANS}

American commerce in the Far East; but beyond this, with the details not yet worked out, was a plan for a roundthe-world transportation line, under unified American control, by way of Japan, Manchuria, Siberia, European Russia and the Atlantic Ocean. Such a railroad and steamship line, if successfully established, would unite for commercial purposes four of the most populous countries on the globe; and would enable the United States not only to take a commanding position in the Orient, but to supply the wants and direct in some measure the commercial activities of hundreds of millions of people in the least developed parts of Europe and Asia.

To most observers at that time a round-the-world transportation line, under American management, would have seemed an unrealizable dream; but Mr. Harriman had made many of his visions 


\section{E. H. HARRIMAN'S}

come true, and he believed that he could give objective reality to this one. His plan was, first, to secure control of the South Manchuria Railway, which Japan, through the fortunes of war, had just acquired from Russia. This road was then in a very unsatisfactory physical condition; but Mr. Harriman proposed to reconstruct and reëquip it, with American capital, and make it the eastern part of his proposed trans Asiatic line. Having secured this essential link, he intended to buy the Chinese Eastern, which he thought the Russians, having lost Port Arthur, would gladly sell, and then acquire transportation or trackage rights over the trans-Siberian and the Russian Government roads from North Manchuria to the coast of the Baltic Sea. These acquisitions, in connection with the Pacific Mail Steamship Company and the American railroad systems that he already con- 


\section{FAR EASTERN PLANS}

trolled, would give him a continuous line more than three quarters of the way around the globe, and it would be a comparatively easy matter, thereafter, to connect up the termini by establishing a line of steamers across the Atlantic from the United States to Russia. ${ }^{*} \mathrm{He}$ anticipated most difficulty in persuading the Japanese to surrender or share the control of the South Manchuria road, which, with the Fushun coal fields adjacent thereto and the southern part of the island of Saghalin, were all that they had been able to get from Russia, by way of indemnity, to cover their colossal war expenditures. However, he had strong hope of success, for the reason that the Japanese were heavily in debt and urgently in need of capital for the improvement of their transportation facilities and the development of their recently acquired territory on the Asiatic mainland. The purchase 


\section{E. H. HARRIMAN'S}

of the Chinese Eastern and the acquirement of the necessary rights over the trans-Siberian he regarded as comparatively easy. Russia had allowed a Baltimore capitalist to build and manage her first railroad, from St. Petersburg to Moscow, and had even asked an American engineer to finance and construct the great road from the Urals to the Pacific. ${ }^{1}$ It seemed probable, therefore, that the Czar would gladly make concessions to American capitalists if, with their aid, he could have the trans-Siberian line double-tracked, properly equipped, and efficiently managed.

'The proposal to finance and build the trans-Siberian railway was made by the Russian Government to a well-known railroad engineer in the United States. The terms offered were liberal, but the amount of capital required was so great that it could not be obtained without the aid, or at least the good will, of the Jewish bankers and financiers in Europe. They, incensed by the treatment of their people in Russia, declined to coöperate, and the American engineer found it impossible to organize a syndicate that would be strong enough to finance the enterprise. 


\section{FAR EASTERN PLANS}

Preparations for the trip to the Orient were begun in July and were soon completed. The party as made up consisted of Mr. and Mrs. Harriman, with their daughters Cornelia, Mary and Carol and their sons Averell and Roland; Mr. and Mrs. Robert Goelet; Mr. R. P. Schwerin, vice president of the Pacific Mail Steamship Company; and Dr. W. G. Lyle, Mr. Harriman's personal physician. They sailed from San Francisco on the steamship Siberia August 16th and, after short stops at Honolulu and Midway Island, arrived in Yokohama on the evening of August 3ist.

The reception given to Mr. Harriman by Japanese officials, financiers and business men was extremely cordial. Representatives of the Bank of Japan and the famous Mitsui Company boarded the steamer as soon as the anchor was down, and when the party 


\section{E. H. HARRIMAN'S}

had landed and taken quarters at the Grand Hotel, calls and assurances of welcome were received from the president and vice president of the Yokohama Specie Bank; the president of the Industrial Bank of Japan; the manager of the Japan Steamship Company; Count K. Inou e one of the "Elder Statesmen"; Baron Iwasaki, Senator Watenabe and Mr. K. Mori, a personal representative of the Minister of Finance.

In Tokyo on the following day, calls from distinguished Japanese continued, and invitations to dinners, lunches, garden parties and other hospitable entertainments were received from Prince Fushimi, Prime Minister Katsura, the Minister of Finance, Count Inouye, Baron Iwasaki, Baron Shibusawa and many prominent business men. On the $4^{\text {th }}$ of September, Minister Griscom gave a dinner at the legation, in honor of Mr. Harriman and his party, which was 


\section{FAR EASTERN PLANS}

attended by the most eminent officials and statesmen in the Japanese capital, including the Premier, the Minister of the Imperial Household, the Minister of Communications, the Vice Minister of Foreign Affairs, the Vice Grand Master of Ceremonies, Count Inouye, Count Toda, and Viscount Inaba. In responding to a toast at this banquet, Mr. Harriman hinted at the plans that he had in mind and prepared the way for future negotiations by saying to the Japanese guests:

You have made great strides in the art of war; but you must look to the arts of peace for those greater achievements which mean prosperity, contentment and happiness. Your people will advance their material welfare still further and more rapidly as they realize the advantages which follow concentration of effort and harmony of operation in their industrial and commercial affairs. From New York to the Pacific 


\section{E. H. HARRIMAN'S}

Coast, and from there to Japan, about ten thousand miles, the railroad and steamship lines are practically under one control and one management. The economies of operation, the comfort to the traveling public, and the advantages to shippers of this concentrated control can be readily appreciated. The benefits to the people of the United States which follow, uirectly and indirectly, are incalculable. The same policy, if followed in Japan, is bound to produce the same results. I hope the day may not be far distant when Japanese business men and American business men, realizing that their interests are common, may be brought into closer relationship.

This was a sufficiently clear indication of Mr. Harriman's purpose to unite, if possible, the transportation systems of America and the Far East; but, unfortunately, circumstances at that time were such as to make the accomplishment of this purpose unusually difficult. 


\section{FAR EASTERN PLANS}

The general outlines of the Portsmouth treaty had just been published in Japan, and the common people, ignorant of their Government's real situation, were intensely dissatisfied with the terms of peace. Their armies, they reasoned, had won every battle in which they had been engaged, and their country was clearly entitled to exact an indemnity from Russia, and to demand the restoration of the whole of the island of Saghalin. The action of their Government in making peace, apparently at the suggestion of President Roosevelt, without securing the legitimate fruits of victory, was an unpardonable exhibition of weakness for which it deserved to be condemned and punished.

No hostile demonstrations were made against Americans, but on the fourth day after Mr. Harriman's arrival, an immense mob of patriotic rioters attacked the residence of the Home Min- 


\section{E. H. HARRIMAN'S}

ister, and when they were opposed by the police, began destroying police stations, police kiosks, and street cars in all parts of the city. Doctor Lyle and Mr. Harriman's private secretary, while on their way to dinner at the residence of the Finance Minister, attempted to pass in jinrikishas through the crowd and quickly became involved in diffculties. The rioters were in a mood to resent almost anything, and raising the cry of "Russians!" they began hooting and throwing stones. Doctor Lyle was struck on the shoulder and slightly hurt, but he and his companion, after some delay, succeeded in reaching safely the Finance Minister's house. Although this attack did not seem to be directed against Doctor Lyle and Secretary McKnight as Americans-it was too dark to see who they were-the Government thought it prudent, at the end of the dinner, to send Mr. Harriman and 


\section{FAR EASTERN PLANS}

his party back to the legation under the protection of an armed escort, and to post guards in the legation grounds.

On the following evening, September 6 th, as the street disorder still continued, a dinner in honor of Mr. Harriman at the Nobles' Club was abandoned, for the reason that the Club happened to be situated near the residence of the Home Minister, which was the storm centre of mob violence. Fearing that the known agency of President Roosevelt as an intermediary in the peace negotiations might turn the hostility of the uninformed but excited populace toward Americans in general, and wishing to relieve Minister Griscom as far as possible from anxiety and responsibility, Mr. Harriman decided to take his party to Nikko for a few days, and to return to Tokyo when the Government should have suppressed the disorder and reëstablished normal condi- 


\section{E. H. HARRIMAN'S}

tions. On the afternoon of September $7^{\text {th }}$, in a special train furnished by the Nippon Railway Company, the Harriman party proceeded to Nikko, where they arrived about 7 P.M. In the course of the two days that they spent in this famous resort, they visited the ancient temples and the mausolea of Ieyasu and Iemitsu; rode through the celebrated avenue of giant cryptomeria trees, and ascended the wild and romantic gorge which leads, at a height of 4,300 feet, to the beautiful mountain lake of Chuzenji. Learning by telegraph that the disorder in Tokyo had ceased, they returned, September i ith, to the American legation, and on the following day Mr. Harriman, Mr. Goelet and Mr. Schwerin were received in audience by the Emperor.

As Mr. Harriman could spend only a limited time in the Far East, and as he desired, before his return, to visit 


\section{FAR EASTERN PLANS}

China and Korea, he was obliged to promote his round-the-world-line enterprise, as far as it could be promoted in Tokyo, by a "whirlwind campaign" of visits and interviews. Between the Ist and I 3 th of September, he made the acquaintance of all the prominent statesmen in Japan, including Marquis Ito, Count Okuma, the Premier and most of the ministers; and succeeded in awakening the interest and enlisting the support of several eminent financiers, including especially Mr. J. Soyeda, President of the Japanese Industrial Bank. Having thus accomplished all that it was possible to accomplish in a few days, he and his party started on the I3th of September for Kyoto and Kobe, leaving further negotiations for the acquirement of the South Manchuria Railway in the capable hands of Minister Griscom and President Soyeda. 


\section{E. H. HARRIMAN'S}

As Mr. Harriman's visit to China and Korea in the latter part of September and the first part of October had no decisive bearing upon the negotiations that chiefly engaged his thoughts, it need not be fully described. Chartering for his party at Kobe the commodious steamer Ohio $I I I$, he sailed through the Inland Sea and across Korea Bay to Port Arthur; visited the battlefields that had given to the fortress its world-wide fame, and then proceeded to Tientsin and Peking. Leaving the Chinese capital on the 28th of September, the party again crossed the Gulf of Pechili and Korea Bay, landed at Chemulpo, and went by rail to Seoul, where they attended a luncheon given in their honor at the Imperial Palace and a garden party arranged by $\mathrm{Mr}$. $\mathrm{T}$. Megata, financial adviser of the Korean Government. On the 8th of October they took a special train to Fusan, at 


\section{FAR EASTERN PLANS}

the end of the peninsula, where the Ohio III met them and carried them to Nagasaki. After inspecting the shipbuilding plant and dry docks in this famous seaport, they sailed again for Kobe, proceeded thence by rail to Yokohama, and on the 9th of October finally returned to Tokyo, thus completing a journey that covered about three thousand miles and occupied twenty-six day's.

During Mr. Harriman's absence, Minister Griscom did all that could be done to promote what seemed to him the best interests of the United States in the Orient by persuading the higher Japanese authorities to consider favorably Mr. Harriman's plans. In his interviews with Premier Katsura, Count Inouye and the Minister of Finance, he took the ground that coöperation with America would be in every way profitable to Japan, by strengthening her credit, furnishing her with capital 


\section{E. H. HARRIMAN'S}

for the improvement of her transportation system, facilitating her trade, and enabling her to develop quickly and fully the material resources of her recently acquired territory on the Asiatic mainland. The South Manchuria Railway was urgently in need of reconstruction and reëquipment, and there was no man in America, perhaps in the world, better qualified by experience and ability to direct such work than the rebuilder of the Union Pacific. Mr. Harriman's relations, moreover, with American bankers and financiers were such that he could secure at once the pecuniary support which Japan needed, but which she alone might not be able to get quickly enough to meet the emergencies of the situation. The suggested project would bring Japan and the United States into much closer relations, both commercially and politically, and if successful it would furnish 


\section{FAR EASTERN PLANS}

a large revenue to the Japanese Government and thus compensate the Japanese people for their failure to get a pecuniary indemnity from Russia.

In his negotiations with the higher authorities, Mr. Griscom was ably assisted by Mr. Durham W. Stevens, who had been in the service of the Japanese Government for more than twenty years, and who had earned the respect and trust of all the Emperor's statesmen and officials. ${ }^{1}$ The result of their joint efforts was in every way encouraging.

${ }^{1} \mathrm{Mr}$. Stevens entered the service of the Japanese Government in 1883 , as counsellor of its legation in Washington. He was soon afterward transferred to Tokyo, where he became a member of the Bureau du Protocol of the Conference for the Revision of Treaties between Japan and Foreign Powers. Between 1887 and 1904 he was engaged in various diplomatic negotiations, and in the latter year he was appointed adviser to the Korean Government at Seoul. He was assassinated in San Francisco in 1908 by a misguided Korean fanatic who regardel him as an enemy of the Korean people, although, in reality, he had always been their sincere friend. 


\section{E. H. HARRIMAN'S}

Premier Katsura said that he would give the matter immediate and serious consideration, and Count Inouye, one of the most influential of the Elder Statesmen, promised that he would call a meeting of the Minister of Finance, the Minister of Communications, and other high officials directly interested, and would try to reach a decision at once. Count Inouye himself was very favorably impressed and said to Mr. Griscom: "We would be very foolish to let such a great chance slip."

When Mr. Harriman returned to Tokyo, on the 8th of October, negotiations were so far advanced that the authorities were ready to consider promptly, if not to accept, a definite proposition; and in three or four days of strenuous activity he succeeded in getting the details settled and reduced to writing in the following memorandum of agreement: 


\section{FAR EASTERN PLANS}

MEMORANDUM of a preliminary understanding, dated October I 2, I905, between His Excellency Count Katsura Taro, representing the Japanese Government, and Mr. E. H. Harriman, representing himself and associates.

A syndicate to be formed to provide capital for the purchase of the South Manchuria Railway, acquired by the Japanese Government, and its appurtenances; the rehabilitation, equipment, reconstruction and extension of the same, and the completion and improvement of the terminals at Tairen (Dalny); and it is understood that the two parties are to have joint and equal ownership in the properties acquired. Permission to work coal mines (in connection with the railroad) to be given to a corporation by special agreement, in which there shall be joint interest and representation.

The principle of development of all industrial enterprises in Manchuria shall be such that each party shall have the right to an equal interest with the other. The Manchurian railroad, with its ap- 


\section{E. H. HARRIMAN'S}

purtenances, rails, cross ties, bridges, superstructure of all character, stations, buildings, platforms, warehouses, docks, wharves, etc., to be taken at their true value, to be determined by joint representation of each party.

The organization to be made on basis that will meet exigencies and conditions as they may exist at the time. As it is deemed advisable to meet the conditions in Japan, the corporation is to be operated with Japanese control. Changes are, however, to be made therein from time to time as far as circumstances will permit, looking toward a final equalization of representation and control. The corporation is to be organized under Japanese law. Mr. Harriman, having agreed for himself to operation through a Japanese company, the only open question is as to his associates agreeing thereto, which he believes they will.

To provide for an arbitrator, it is agreed that Mr. Henry W. Denison shall be appointed to fill that place. ${ }^{1}$

${ }^{1} \mathrm{Mr}$. Denison, at that time, had been legal adviser of the Japanese Foreign Office for about a quarter of a 


\section{FAR EASTERN PLANS}

In case of war between Japan and China, or Japan and Russia, the railroad shall at all times obey the instructions of the Japanese Government in the matter of the conveyance of troops and war materials, and the Japanese Government is to compensate the railroad for services rendered and protect it against agressions at all times.

It is agreed that Mr. J. Soyeda, President of the Industrial Bank of Japan, shall be the medium of communication between the parties hereto.

The including of any outside interests (other) than the parties hereto shall be done only after conference and mutual agreement.

With this memorandum of agreement in his possession, Mr. Harriman sailed from Yokohama in the steamship Si-

century. He had been repeatedly decorated by the Emperor for distinguished service, and enjoyed the implicit trust of both Government and people. He was born in Guildhall, Vt., in I 846 and received his higher education in the Columbian (now George Washington) University. 


\section{E. H. HARRIMAN'S}

beria on the afternoon of Friday, October I2th. He had not accomplished all that he desired to accomplish, but he had at least "started something," and there seemed to be a fair prospect that the concession thus obtained would ultimately lead to the consolidation of Japanese and American transportation interests on the Asiatic mainland, and greatly extend and promote the commerce of the United States in that part of the Orient.

Unfortunately, while Mr. Harriman was at sea, on his way to San Francisco, all his Far Eastern plans were suddenly blocked by an obstacle that he had neither foreseen nor considered. Three days after he sailed from Yokohama, Baron Komura, the Japanese Minister of Foreign Affairs, returned to Tokyo from the United States, bringing the treaty that he and Minister Takahira had just negotiated with the Russian 


\section{FAR EASTERN PLANS}

plenipotentiaries at Portsmouth. As soon as the Harriman-Katsura agreement for joint control of the South Manchuria Railway was shown him, he said: "It cannot possibly be carried out, because it is inconsistent with Article VI of the treaty that we have just made with Russia." The article in question provided that the transfer of the South Manchurian road from Russia to Japan should be made only with the consent of the Chinese Government. Until, therefore, such consent should be obtained, Japan had no legal rights that could be shared with Mr. Harriman. Aside from this, Baron Komura was opposed to the Harriman-Katsura agreement on its merits. The Japanese people were already so dissatisfied with the Portsmouth treaty that they had resorted to mob violence as a protest against it, and their discontent would be greatly increased if they should learn 


\section{E. H. HARRIMAN'S}

that their Government had sold to a Japanese-American syndicate nearly all that they had gained in two years of successful war. To have made peace without securing a pecuniary indemnity was bad enough; but to sell more than half the fruits of their victory to the Americans, and thus throw open to foreign competition the commercial field which they had bought with their treasure and blood would seem to them intolerable.

Baron Komura's arguments and influence were too strong for the supporters of the Japanese-American agreement, and in less than a week a change of policy was decided upon. When Mr. Harriman, with his mind full of plans for the future, arrived in San Francisco, he received from the Japanese consul there the following note:

"I beg to inform you that I have been instructed by Count Katsura, of my Gov- 


\section{FAR EASTERN PLANS}

ernment, to deliver the following message to you immediately upon your arrival in San Francisco:

"'The Japanese Government have found it necessary to institute a more thorough investigation and examination of the questions which are the subject of memorandum of October I2, I905, and they consequently request you to regard the memorandum as in abeyance until they are able to communicate with you more fully regarding the matter.'"

Ten days later, when Mr. Harriman had reached New York, he received the following cable message from Mr. J. Soyeda, President of the Industrial Bank of Japan:

E. H. Harriman

Tokyo, October 30, I905.

New York.

Prime Minister requests to forward following confidential message to you explanatory message handed you by Japanese consul San Francisco: 


\section{E. H. HARRIMAN'S}

"Having considered detailed report made by Minister Foreign Affairs on his return home, and having in view pacific attitude Chinese Government on railroad question, Japanese Government has come to conclusion that question embodied in memorandum, October I 2 th requires more thorough and complete examination than possible at present time. As you are aware, Portsmouth treaty provides for consent of China regarding transfer to Japan of railroad property, and for agreement with Russia regulating connecting railroad service. Until agreements with China and Russia are concluded, impossible to determine precisely what rights and properties are included in the transfer, or what earning capacity of railroad is likely to be. Without full knowledge on these points impossible to make definite arrangements for working railroad and property which would prove satisfactory to either Japanese Government or E. H. Harriman. Consequently Japanese Government deem wise request $\mathrm{E}$. $\mathrm{H}$. Harriman to regard 


\section{FAR EASTERN PLANS}

said memorandum as in abeyance for the time being. Japanese Government will proceed, as soon as possible, to conclude necessary international agreement. Such agreement will probably necessitate some essential change in proposed arrangement with Mr. Harriman. But in any event, Japanese Government will consult him before making arrangement with private capital."

\section{SOYEDA.}

This cable message was the result of a compromise between Baron Komura and the supporters of the HarrimanKatsura memorandum. The former advocated immediate cancellation of the agreement, for the reason that it was inconsistent with Article VI of the Portsmouth treaty. In view, however, of all the circumstances, and especially of Katsura's ignorance of the stipulation regarding Chinese consent, Baron Komura agreed to regard the memorandum as "in abeyance," and to leave open the 


\section{E. H. HARRIMAN'S}

possibility of confirmation at a later time, provided no objection should be raised by the Government of China.

If the Japanese Minister of Foreign Affairs had been previously consulted, and had favored the agreement on its merits, he might possibly have found some means of dealing with the Chinese complication; but he had never met Mr. Harriman and had not been impressed, as had his colleagues, by the latter's forceful personality; he doubted the expediency of sharing control of the South Manchurian road with a syndicate about which he knew little or nothing; and he believed that the agreement, if allowed to go into effect at that time, would increase his own unpopularity in Japan, and would render extremely difficult, if not wholly impossible, the negotiation of the treaty with China that he then had in contemplation. He therefore insisted upon 


\section{FAR EASTERN PLANS}

postponement, at least, and the other members of the ministry yielded.

In this thwarting of Mr. Harriman's plans there seems to have been no intentional breach of faith on the part of the Tokyo authorities. It was simply a case in which one branch of the Government, acting independently, concluded a treaty that nullified action taken almost simultaneously by another branch. Count Katsura did not know that Baron Komura had agreed in Portsmouth to make the transfer of the railroad conditional upon Chinese consent, while Komura, in concluding such agreement with Russia, was ignorant of the Tokyo memorandum. One compact or the other had to be set aside, and in holding the Harriman agreement "in abeyance" while he negotiated with China, Baron Komura thought, perhaps, that he was making the best of an accidental and unfortunate situation. But be that as 


\section{E. H. HARRIMAN'S}

it may, he started for Peking with Mr. Denison, on the 6th of November, leaving the railroad matter in this unsettled state.

Negotiations with the Government of China for a new treaty occupied more than a month, and Mr. Harriman was not informed of the result until the $r 5^{\text {th }}$ of January I906, when he received from Mr. Soyeda the following cable message:

E. H. HARRIMAN,

Tokyo, January 15, 1906.

New York.

Baron Komura returned on the rst of January and the new Cabinet was formed on the 7 th. I have been urging the necessity of informing you what to be done, and am now asked to wire you. Count Katsura requests me to let you know that obtaining from China consent contemplated by Article VI Portsmouth, N. H., treaty it was necessary to provide that Manchurian railway should be worked by company composed exclusively of Japanese and Chinese share- 


\section{FAR EASTERN PLANS}

holders, following in that respect terms of original concession to Russia. Count desires me to convey expression of regret that, in view of above circumstance, he is compelled to ask you regard memorandum of October I2, I905 as of no effect, as it is manifestly impossible to make any arrangement based on it. He adds, however, that the Japanese Government entertain a doubt as to possibility of Japanese and Chinese capital alone being sufficient to meet requirements of necessary improvements and extension of Manchurian railway, and that therefore should an occasion arise in future enabling them to open negotiations with foreign capitalists, on a different basis, a fresh consultation may be held with you. I desire to add Count has been relieved of his position as Prime Minister, and send this telegram after consulting with Marquis Saionji, his successor.

Soyeda.

In a letter written to Minister Griscom in January, I906, Mr. H. W. Deni- 


\section{E. H. HARRIMAN'S}

son, legal adviser of the Japanese Foreign Office, gave the following explanation of Baron Komura's failure to get the consent of China to the HarrimanKatsura agreement:

"The Japanese Government have secured the consent of China to the assignment of the railroad (the South Nianchurian) between Port Arthur and Chang-chun, subject to the same terms and conditions that attached to the original grant to Russia; that is to say, the railroad is to be worked by a company composed exclusively of Japanese and Chinese shareholders. You will find the original concession to Russia in Rockhill's book 'Treaties and Conventions with and concerning China and Korea,' pp. 207-224, and I enclose a newspaper copy of the official version of Baron Komura's agreements with China. . . . If the Chinese avail themselves of the opportunity of taking half a share in the Manchurian enterprises, a definite understanding on the 


\section{FAR EASTERN PLANS}

basis of the memorandum of October I 2 th is impracticable. There is at the present time a very strong anti-concession wave sweeping over China. The Government are endeavoring, by hook or by crook, to get back the grants already made. They cancel the concessions in case of default in any direction, and they buy back the grants if no grounds for cancellation exist. In this frame of mind, and being unable to cancel or repurchase the Manchurian concessions, it is more than likely that China will gladly take the one-half interest in the enterprise. In that case I believe some arrangement on new lines will be possible, but only if the negotiations are undertaken by a man of force and prestige like Mr. Harriman."

In the spring of I906, Mr. Jacob $\mathrm{H}$. Schiff, of the firm of Kuhn, Loeb \& Co., happened to visit the Far East and, at the request of his old friend and associate, Mr. Harriman, made an attempt to revive the 1905 agreement; but Baron 


\section{E. H. HARRIMAN'S}

Komura was as much opposed to it as ever, and after a number of conferences the negotiations were again dropped.

Thus ended Mr. Harriman's attempt to get control, or partial control, of the South Manchuria Railway, as an essential link in his projected round-theworld transportation line. His ill success, however, did not shake his faith in the practicability of the enterprise, but merely led him to consider other means of bridging the gap between the Gulf of Pechili and the trans-Siberian road. The difficulties in the way were very great. A new and independent line through Manchuria or Mongolia could not be built without Chinese consent, and the Chinese, at that time, were strongly opposed to the granting of any more railroad concessions to foreign syndicates. So far, moreover, as a line through Manchuria was concerned, they themselves were almost powerless, for 


\section{FAR EASTERN PLANS}

the reason that, in the treaty of December, I905, with Japan, they had agreed "not to construct any main line in the neighborhood of and parallel to the South Manchuria Railway." Even, therefore, if they had been willing to let Mr. Harriman build a road from the Gulf of Pechili to the terminus of the Chinese Eastern, they could not do so, because it would necessarily be a "main line in the neighborhood of and parallel to the South Manchurian."

Mr. Harriman thought, at one time, of building a road across the Gobi Desert by the old caravan route, passing through Kalgan and Urga and connecting with the trans-Siberian near Irkutsk; but as the distance would be great- $\mathrm{I}, 200$ miles or more-and as most of the country to be traversed was so barren as to promise little in the way of agricultural development, this scheme was soon dismissed as imprac- 


\section{E. H. HARRIMAN'S}

ticable. $^{1}$ The only alternative was a new line, about four hundred and fifty miles in length, from the Gulf of Pechili to the trans-Siberian Railway at Tsitsihar. This road, although nearly parallel with the South Manchurian, would be separated from it by an average distance of one hundred and seventy miles, and consequently would not be in the prohibited "neighborhood."

In the early part of I906, Mr. Harriman received full reports on the trade, industry and resources of northeastern China from Colonel Holabird and Mr. Wallace, two experts whom he had sent to make investigations in the Far East; and in that and the following year he

IIt is not certain, however, that even this line would have been unprofitable. The Chinese themselves afterward began the construction of four hundred miles of railway along this route, and on the Peking-Kalgan section, which was completed in I9I2, the net profits of operation in $19 \mathrm{r} 3$ were twenty per cent. on the investment. 


\section{FAR EASTERN PLANS}

was kept fully informed with regard to railroad affairs in Siberia and Manchuria by Mr. Willard D. Straight, Consul General of the United States at Mukden. ${ }^{1}$

For a year or more, no opportunity to promote the Far Eastern enterprise

${ }^{1} \mathrm{Mr}$. Straight was a young graduate of Cornell University whose acquaintance Mr. Harriman made in October, 1905, at the house of Edward Vernon Morgan, American minister to Korea. Mr. Straight was then Vice Consul General in Seoul, but he had previously been correspondent of Reuter's Agency and the Associated Press in Korea and Manchuria and had spent two years in the service of the Chinese Imperial Maritime Customs at Nanking and Peking. He impressed Mr. Harriman as a young man of character and force, and one whose ability and experience might make him a valuable assistant in such an enterprise as that which was then in contemplation. When the American legation in Seoul was closed, in the fall of $1905, \mathrm{Mr}$. Straight went with Minister Morgan as private secretary, and when Mr. Morgan was appointed minister to Cuba in 1906, he accompanied him to Havana. A few months later the State Department transferred him to China and made him Consul General at Mukden. On his way back to the Far East, in the summer of 1906, he spent a weekend at Arden, where Mr. Harriman discussed with him the railroad situation in Manchuria and arranged to keep in touch with him by means of correspondence. 


\section{E. H. HARRIMAN'S}

presented itself, but in September, 1907, Lord Ffrench, representing Pauling \& Co., of London, and Mr. J. O. P. Bland, representing the "British and Chinese Corporation," secured from the Chinese Government the right to extend the Chinese Imperial Railway from Hsinmin-tun to Fakumen, with the privilege of building, ultimately, to the transSiberian at Tsitsihar. As this seemed to open the way for such a Russian connection as Mr. Harriman had in view, Mr. Straight wrote him, in September I907, suggesting an alliance with the British syndicate, as a means of securing the essential link in the projected round-the-world line without the coöperation of the Japanese. Mr. Harriman replied by cable, however, in October I907, that, owing to the panic of that year, financial conditions were such as to prevent the raising of the necessary funds. 


\section{FAR EASTERN PLANS}

In the summer of I9o8, when the financial situation in the United States had somewhat improved, Mr. Harriman decided to make another move in the Far East, and requested Secretary Root to recall Consul General Straight, in order that American capitalists might discuss with him the expediency of making a loan to China for agricultural development and railroad construction in Manchuria. Meanwhile Mr. Straight had secured from Tang Shao-yi, the Chinese governor at Mukden, a signed memorandum of agreement which was to form the basis of negotiations for a loan of $\$ 20,000, \infty 00$. With this sum it was proposed to establish a Manchurian Bank, which should coöperate with American and Chinese interests in the construction of a railway from Tsitsihar to Aigun. Then, if the bank and the American capitalists could come to an agreement with Pauling \& Co. who had 


\section{E. H. HARRIMAN'S}

the right to build a road southward from Tsitsihar to Hsin-min-tun, it would be possible to construct a trunk line from the Gulf of Pechili to the Amur, and thus bridge the gap between the Pacific Ocean and the trans-Siberian road.

In September, I908, Consul General Straight returned to the United States, bringing with him the memorandum of agreement with Tang Shao-yi for the $\$ 20,000, \infty 00$ loan. Through the influence of Mr. Harriman, and with the cognizance and approval of the Secretary of State, Kuhn, Loeb \& Co., agreed to undertake this loan, provided all the details thereof could be satisfactorily arranged. Late in November, Tang Shao-yi came to Washington, ostensibly to thank President Roosevelt for the remission of part of the Boxer indemnity, but really, in great part, to negotiate the proposed loan for the establishment of the Manchurian Bank. 


\section{FAR EASTERN PLANS}

Here again, however, Mr. Harriman's plans were blocked by events that could not possibly have been foreseen. 'Tang Shao-yi's appointment had been made through the influence of his friend Yuan Shi-kai, who was then Grand Councillor and head of the Chinese Foreign Office, and who was greatly interested in securing American capital for the development of Manchurian resources. About the middle of November, I908, both the Emperor and the Empress Dowager of China died, and Prince Chun, an enemy of Yuan Shi-kai, became regent. This undermined Yuan's power, and led, a few weeks later, to his dismissal from office. Tang Shao-yi, thus left without support at home, became discouraged, and the matter of the loan was allowed to drop.

Mr. Harriman, however, continued his negotiations for the acquirement of a Manchurian line, both with Russia and 


\section{E. H. HARRIMAN'S}

again with Japan. In the summer of 1909, after he was stricken with mortal illness, he secured a promise from the Russian Minister of Foreign Affairs, Mr. Kokovtsef, that upon the latter's return from a trip that he was about to make to the Far East, he would recommend the sale of the Chinese Eastern Railway to American interests. But even this partial success came too late. On the 9th of September Mr. Harriman died, and there was no one left in America capable of undertaking, much less of carrying through, such a colossal enterprise as the establishment of a roundthe-world American transportation line. Whether the "Master Builder" himself could have accomplished it, if he had lived, it is impossible to say; but the results of successful accomplishment might have influenced profoundly the world's history. No one who has studied Mr. Harriman's 'constructive and 


\section{FAR EASTERN PLANS}

administrative methods can doubt that if he had ever acquired even partial control of the trans-Siberian railway, he would have doubled or trebled its carrying capacity. Then, when the great war of I9I4 came, Russia would have been able to draw heavy artillery and ammunition from Japan and America over an efficient through line of great capacity, and would not have been reduced to such straits as she was when her troops, largely without proper weapons and almost wholly without reserves of ammunition, were forced out of Poland and driven half way to Petrograd. Her defeats in the war with Japan in 1904-5 were mainly due to the inadequacy of the trans-Siberian road as a means of speedy transportation, and her reverses on the German frontier, ten years later, were due, in part at least, to the same cause. During the winter and spring of every year, the rail- 


\section{FAR EASTERN PLANS}

road to the Pacific was her only open line of communication with the outside world, and it never was in physical condition to meet the demands made upon it. If, reconstructed and reëquipped by Mr. Harriman and the American syndicate, it had been made part of a great international transportation system, it might have become the decisive factor in the struggle with Germany in I9I4-I9I5, and might thus have changed the earlier stages, if not the whole course, of the great world war. 


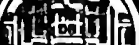 \\ (19.9.}

THE COUNTRY LIFE PRESS

GARDEN CITY, N. Y. 


$$
\text { - }
$$





$$
\text { , }
$$



LOS ANGELES, CALIFORNIA $90095-1388$

Return this material to the library from which it was borrowed.

DE

A

06

能

Fit) 


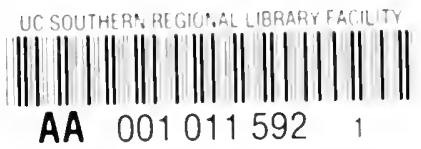




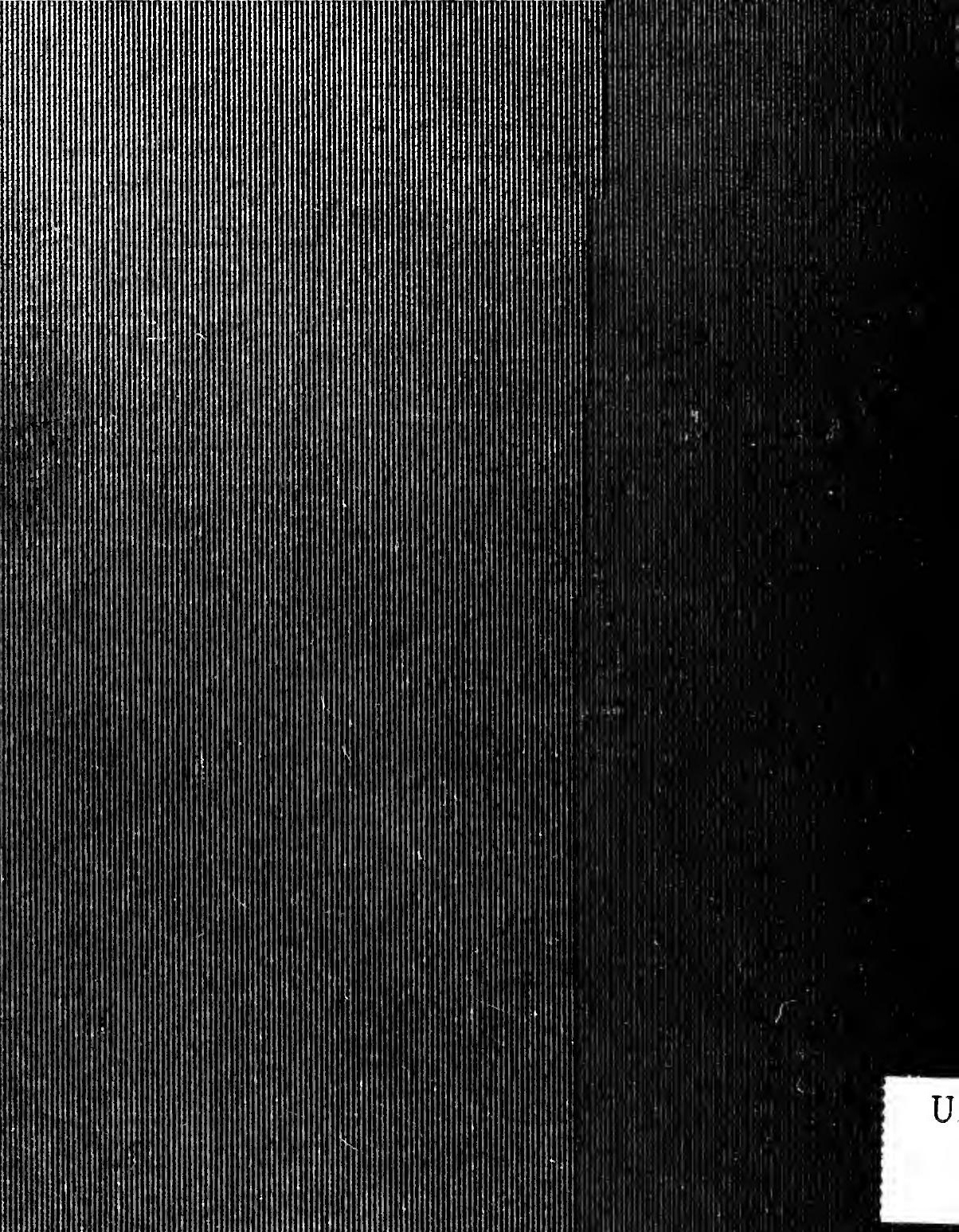
3 (1) m m

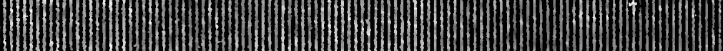
I)

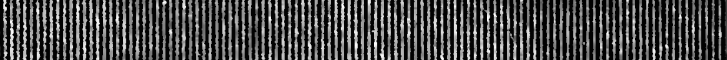

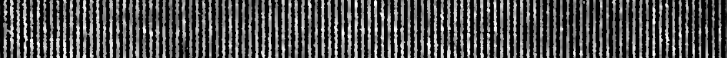

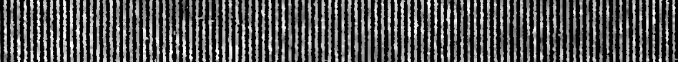
m - m - m - m  